\title{
The Relationship between Resilience and Perceived Practicum Stress: The Mediating Role of Self-Efficacy
}

\author{
G. K. Nguia, Y. F. Lay ${ }^{b^{*}}$ \\ ${ }^{a}$ Gaya Teacher Education Institute, Kota Kinabalu, Sabah, Malaysia \\ ${ }^{b}$ Faculty of Psychology and Education, Universiti Malaysia Sabah, Sabah, Malaysia \\ *Corresponding author: layyf@ums.edu.my
}

\begin{abstract}
The purpose of this study is to determine the mediating role of three subdimensions of self-efficacy (instructional strategies, classroom management and students' involvement) on the relationship between resilience and trainee teachers' perceived practicum stress. Hypothesized multivariate model was tested using partial least square-structural equation modeling (PLS-SEM) with SmartPLS3.0 to determine the mediating effect self-efficacy on of these variables. The reflective measurement model analysis indicated a good statistical fit. The structural measurement model showed that resilience has a significant relationship with instructional strategies, classroom management and students' involvement. The relationship between resilience and perceived practicum stress was also significant. However, the result showed that although classroom management was a significant mediator of the relationship between the studied variables, instructional strategies and students' involvement were not. Hence, this implied that efficacy in classroom management enables trainee teachers to reduce perceived practicum stress more than efficacy in instructional strategies and students' involvement.
\end{abstract}

Keywords: Self-efficacy; resilience; perceived practicum stress; classroom management; instructional strategies; students' involvement

(C) 2017 Penerbit UTM Press. All rights reserved

\subsection{INTRODUCTION}

Teaching is a means of delivering education at the classroom level. To ensure that students receive the best education, teachers need to develop high self-efficacy as this ensures teachers are confident and believing in their capabilities to teach (Fives, 2003). Wood and Bandura (1989) defined self-efficacy as "an individual's perception of his/her ability to fulfill demands in a particular situation." Based on the Cognitive Social Theory, Bandura (1999) explains that internal and external factors influence one's behavior. In real teaching situation, high level of stress is often indicated (Caires, Almeida \& Martins, 2010; Hamaidi, Al-Shara, Arouri \& Awwad, 2014; Kyriacou \& Stephens, 1999). Hence, stress is an external event that may influence one's behavior in a cognitive manner. How one deals with stress is determined by past experiences (Bandura, 2001). It is shown that high efficacious teachers are able to manage stress as they showed greater work commitment, more open to innovation, more satisfied with work and invest more efforts to teach as well as experiencing lesser level of burnout. Teaching practicum becomes the best avenue to groom teachers towards having greater resilience and self-efficacy for the teaching in the real world (Goh \& Matthews, 2011). Hence, it is a compulsory and necessary component of any teacher education program (Farrell, 2008; Goh \& Matthews, 2011; Mutlu, 2015). Students can gain the optimum benefits from their teaching practicum as they develop their resilience against practicum stress. Bonnano (2012) explained resilience as the ability to deal with life challenges such as work stress or personal stress while still maintaining to live a positive and healthy life. Wagnild and Young (1990) define resilience as the emotional stamina exhibited through courage and adaptation that are employed when one's life situation is not easy. Resilience means that the individual is able to recognize stress, evaluate one's realistic capabilities to act and solve problems effectively (Bonnano, 2012; Hong, 2012; Wagnild \& Young, 1990). Therefore, the purpose of this study is to determine level of resilience, self-efficacy and perceived practicum stress, and the mediating role of self-efficacy on the relationship between resilience and perceived practicum stress.

\subsection{THEORETICAL FOUNDATION OF THE STUDY}

\section{Perceived Practicum Stress}

Ralph (2007) defined practicum as a supervised practical experience in the form of training within a job normally conducted as a pretraining preparation of a profession across disciplines. Therefore, a teaching practicum serves to allow trainee teachers with the experience to become a teacher based on the school teaching experience that they go through during practicum (Tuli \& File, 2009). It is not enough for teachers to know the pedagogy but also the methods to deliver the contents, deal with students' characteristics and combine all these knowledge and skills to become competent educators. However, stress often accompany teaching and this is also associated with practicum (Caires et al., 2010). According to Abebe and HaileMariam (2011), stress refers to any factor that acts either internally or externally on a person and causing difficulty to adapt, and therefore need more effort from the individual to maintain the balance between equilibrium 
between self and the external environment. McGrath (1984) stated that stress causes an individual to go beyond his resources and ability to deal with it.

The incidence of stress can be explained by stress models such as the Person-Environment Fit Model (French \& Kaplan, 1972), the Karasek Demand-Control Model (Karasek \& Theorell, 1990), the Lazarus Transactional Process Model (Lazarus \& Folkman, 1984) and the National Institute of Occupational Safety and Health (NIOSH) Model (NIOSH, 2002). Using the Person-Environment Fit Model, job stress relates to the job characteristics that threatens the individual due to weak matching between the worker's ability and job demand (Deniz, Noyan \& Ertosun, 2015). A mismatch between the person and the environment causes a psychological stress that contributes to physical disturbances. When there is a match between the person and environment, then adaptation and performance are less required (Faroooqui \& Nagendra, 2014). The Karasek Demand-Control Model which was previously known as the Job Strain Model explains that the biggest risk to physical and mental health comes from high demand on psychological load along with poor control or latitude of decision to fulfill the demand (Pinto, Darwood \& Pinto, 2014). The combination of high work demand and a relatively small amount of control contributed to reduced productivity and higher risk towards health-related problem (Hokerberg, Reichenheim, Faerstein, Passos, Fritzell, Toivanen \& Westerlund, 2014; Pinto, Dawood \& Pinto, 2014). The Lazarus Transactional Model applied in job stress explained the difference between stressors at the work place and the emotional reaction that resulted when stressors are assessed cognitively as threatening (Lazarus, 1991). The NIOSH definition of job stress stated it as a physical and emotional responses that happen when job needs do not match with capabilities, resources or needs of the worker (NIOSH, 2002). This model explicitly identifies that exposure to stressful work situation results in job stress but individual and other situational factors can strengthen or weaken this influence. These models implied that stress is caused by internal and external factors but can be overcome or managed with good coping strategies. To overcome stress, personal resources are needed to maintain or increase the sense of well-being (Baloglu, 2008). Resilience contributes to coping with stress and strengthened self-efficacy, therefore enable a person to deal with challenges (Soave, 2014).

\section{Resilience}

Resilience is the ability to make a comeback from adversity, frustration and misfortune (Ledesma, 2012). Perry (2002) defines resilience as the capacity of an individual to face stressors without having any significant negative effects on his functioning. In psychiatry, resilience refers to the physiological and biological strengths that people use to deal with change successfully (Flach, 1988) while in developmental psychopathology, it refers to the ability to cope with challenges and threat while at the same time, maintains an internal and integrated sense of self (Garmezy \& Masten, 1986). Conner (1993) added that in the change management field, resilience means the ability to show both strength and flexibility while showing minimal dysfunctional behavior. Resilience theory is a well-researched subject in many disciplines. Thriving which is described as a person's ability to go beyond one's original level of function and to grow and function even though there is repeated exposure to stressful situation (O'Leary, 1998) is an act of being resilient. The Constructivist Self-Determination Theory (CDST) can be used to explain about resilience (Saakvitne, Tennen \& Affleck, 1998). According to this theory, a person' response to stressful situation is determined by the particular meaning attached to the stressful situation. The meanings may include the person's experience of self, age and development stage, biological and psychological resources, interpersonal experiences and expectations and also, his social, cultural and economic background (Nishikawa, 2006).

\section{Self-Efficacy}

Fives (2003) defines self-efficacy as a motivational construct that exhibits the perception and belief of teachers about specific teaching tasks. Wood and Bandura (1989) explained self-efficacy as the belief that an individual has on his or her ability to mobilize motivation, cognitive resources and the needed actions to fulfill the demands in a particular situation. According to Tschannen-Moran and WoolfolkHoy (2001), teacher efficacy can be related to their belief in completing their critical tasks which are related to students' involvement, classroom management and instructional strategies. Thus, self-efficacy is about a person's belief about his or her capability to do a particular task. Maddux (2011) added that self-efficacy is the belief that someone has on his or her ability to coordinate the skills and abilities to achieve desired goals in a particular domain and situation. Self-efficacy is rooted in the Bandura's Cognitive Social Theory (1986) that stresses on social experience and observed learning in the individual's personality development process. According to this theory, the behavioral choice of an individual in a particular situation depends on his or her personal observation. The observed behavior is retained in the person's memory and contributes to define future cognitive process and social behavior. Three factors determine the action of an individual: cognitive or personal factor, environmental factor and behavioral factor (Qureshi, 2015). Cognitive factors refer to knowledge, expectation and attitude whereby social norms, access to the community and influence on others are environmental factors (Bandura, 2005). Bandura (2001) explained that the Cognitive Social Theory believes in human as the agent of life and to be one, is to make things happen intentionally with his or her action. Human does not response mechanically to a stimulus but do something to change his environment. External factors such as practicum stress influence people's behavior via cognitive process. This cognitive process partly influence how external events are perceived and used in future events by individuals. The thinking, expectation and behavior of a person in the future is subjected to the experience they gather from their action now. Therefore, trainee teachers may exhibit different level of selfefficacy during the practicum based on their previous experience.

\subsection{CONCEPTUAL FRAMEWORK}

Individuals with high resilience are often able to deal with stress using positive means (Bonnano, 2012). In the context of practicum, resilience is the trainee teachers' ability to handle their stressful work situation (Beltman, Mansfield \& Price, 2011). Discipline issues, time management and selection of lesson contents may contribute to stress (Rieg, Paquette \& Chen, 2007). However, stress is not something that is universal because some people seem to cope with stress better than others (Abebe \& HaileMariam, 2011). Highly resilient teachers were observed to have better coping ability against stress (Castro, Kelly \& Shih, 2010). Efficacy is also related to a teacher's belief that that are effective as teacher (Sosa \& Gomez, 2012). Studies showed that individuals with high self-efficacy can withstand a task longer than those with lower self-efficacy. Therefore, resilience and self-efficacy are also inter-related (Hong, 2012; Sosa \& Gomez, 2012). 
The conceptual framework in this study shows the relationship between resilience and perceived practicum stress and this relationship is mediated by the three sub-components of self-efficacy: students' involvement, classroom management and instructional strategies. There are many studies to study the effect of self-efficacy as a mediator. For instance, Mohamadi and Asadzadeh (2012) tested the mediating role of -teachers' self-efficacy beliefs in the relationship between sources of efficacy information and students' achievement. Canpolat (2012) examined the mediating role of self-efficacy in the relationship between class climates and goal orientation. Saricam (2015) investigated the mediating effect of self-efficacy in the relationship between subjective vitality and school burnout. The relationship between resilience and self-efficacy, resilience and stress, and self-efficacy and stress are supported theoretically (Soave, 2014) but there are hardly any formal tests in the literature to show that self-efficacy can act as a mediator in the relationship between resilience and perceived stress. Additionally, there are also no published literature that examines the effect of self-efficacy dimensions - students' involvement, classroom management and instructional strategies - on the relationship between resilience and stress. Therefore, this study provides answer to the question: does students' involvement, classroom management or instructional strategies mediate the relationship between resilience and perceived stress?

\subsection{METHODOLOGY}

\section{Research Design}

The research undertook a positivist philosophy that underpins an empirical study to determine the predictive ability of the exogenous variables to explain variance in the endogenous variable. A multivariate analysis using PLS-SEM was employed to develop the structural model of relationships among the variables. This quantitative method is widely used in many field of studies including information management system (Ringle, Sarstedt \& Straub, 2012), marketing (Hair, Sarstedt, Ringle \& Mena, 2012), strategic management (Hair, Sarstedt, Pieper \& Ringle, 2012), accounting (Lee, Petter, Fayard, \& Robinson, 2011), family business research (Sarstedt, Ringle, Smith, Reams \& Hair, 2014), operational management (Peng \& Lai, 2012), and other organizational research (Sosik, Kahai \& Piovoso, 2009). PLS-SEM is ideally and aptly chosen for this study as it enables the measurement of latent variables such as resilience, self-efficacy and perceived stress (Wong, 2013).

\section{Population and Sampling Method}

The population of this study was identified as trainee teachers from a teacher education institute in Kota Kinabalu, Sabah, who have completed their first teaching practicum. The participants were sampled using a purposive sampling technique. Sampling adequacy adhere to Cohen's principle of sample size adequacy (Cohen, 1998; Henseler, Ringle \& Sinkovics, 2009). A total of 200 trainee teachers was included in the survey.

\section{Research Instrument}

A questionnaire was developed which comprises of four sections: the respondent's profile, resilience, self-efficacy and perceived practicum stress. The Resilience Scale was adapted from Wagnild and Young (1993) which consisted of 25 item using a 7-point Likert scale. Resilience was based on percentage scores with marks between 25 to 100 as very low, 101 to 115 as low, 116 to 130 as moderately low, 131 to 145 as moderately high, 146 to 160 as high and 161 to 175 as very high. Wagnild and Young (1993) reported that the scale has a high reliability with Cronbach's Alpha of 0.91 . Item-to-total correlations ranged from 0.37 to 0.75 with majority falling between 0.50 and 0.70 . All were significant at $\mathrm{p}<0.001$. The Self-Efficacy Scale was adapted from the Teachers' Sense of Efficacy Scale initially developed by Tschannen-Moran and Woolfolk-Hoy (2001). The scale consists of 12-items with 9-point Likert Scale. Self-efficacy is divided into three sub-dimensions of students' involvement, classroom management and instructional strategies. Tschannen-Moran and Woolfolk-Hoy (2001) stated that the scale has a high reliability with alpha coefficient of 0.90 and was significantly correlated to other teacher selfefficacy measurement. Cohen's (1998) Perceived Stress Scale was used to develop the Perceived Practicum Stress in this study. The scale comprises of 10 items using a 5-point Likert scale that begins with a " 0 " for "never" and " 4 " for "very often" to indicate the frequency of experiencing stress. The scale is widely used in studies that evaluates stressful events in stress management program (Leon, Hyre, Ompad, DeSalvo \& Muntner, 2007; Malinauskas, Malinauskiene \& Dumciene, 2010; Waldman, Diez, Arazi, Linetzky, Guinjoan \& Grancelli, 2009; Lane, Seskevich \& Pieper, 2007). The 10-item scale has a good reliability with Cronbach's Alpha between 0.78 and 0.91 , and a testretest reliability of between 0.55 and 0.85 (Cohen et al., 1983).

\section{Data Analysis}

IBM SPSS 23.0 was used to create the database and run descriptive statistical analysis to determine the level of resilience, self-efficacy and perceived practicum stress. SmartPLS 3.0 was used to run inferential statistics to assess the reflective measurement models and the structural model.

\subsection{RESULTS AND DISCUSSION}

\section{Demographic Profiles of the Respondents}

The study was participated by $141(70.5 \%)$ female and $59(29.5 \%)$ male trainee teachers who are 25 years old and below. These trainees have completed their first teaching practicum in $8^{\text {th }}$ Semester of their Bachelor in Education program. Majority of the respondents majored 
in Teaching of English as a Second Language, TESL (64.5\%) while the remaining majored in Chinese Language (26.0\%) and Mathematics $(9.5 \%)$.

\section{Results of the Descriptive Analysis}

Based on the descriptive analysis, the level of resilience self-efficacy and perceived practicum stress was determined as presented in Table 1. The mean percentage score for resilience indicated a moderately low level (mean percentage $=128.36$ ). Each sub-dimension of selfefficacy and overall self-efficacy showed moderate level with mean scores of 6.17 for students' involvement, 6.07 for classroom management, 6.13 for instructional strategies and 6.20 for overall self-efficacy. Perceived practicum stress with a mean score of 2.54 was also indicative for moderate level.

Table 1 Descriptive analysis results on resilience, self-efficacy, and perceived practicum stress

\begin{tabular}{|c|c|c|c|}
\hline Research Variables & Mean & Standard Deviation & Level \\
\hline Resilience $^{1}$ & 128.36 & 20.61 & Moderate Low \\
\hline Perceived Practicum Stress ${ }^{2}$ & 2.54 & 0.68 & Moderate \\
\hline \multicolumn{4}{|l|}{ Self-Efficacy ${ }^{3}$} \\
\hline Students' Involvement & 6.17 & 1.26 & Moderate \\
\hline Classroom Management & 6.07 & 1.14 & Moderate \\
\hline Instructional Strategies & 6.13 & 1.29 & Moderate \\
\hline Overall Self-Efficacy & 6.20 & 1.16 & Moderate \\
\hline \\
\hline \multicolumn{4}{|c|}{$\begin{array}{l}\text { Note: } \\
\text { 1. Level is based on total score values: <100 (very low); 101-115 (low); 116-130 (moderate low); 131-145 (moderate high); 146-160 }\end{array}$} \\
\hline \multicolumn{4}{|c|}{ 2. Level is based on mean values: $<1.333$ (low); $1.334-2.667$ (moderate); $>2.667$ (high) } \\
\hline \multicolumn{4}{|c|}{ 3. Level is based on mean values: $<3.667$ (low); $3.668-6.335$ (moderate); $>6.335$ (high) } \\
\hline
\end{tabular}

\section{Reflective Measurement Model Assessment}

Table 2 presents the result of the reflective measurement model assessment. The indicator reliability as indicated by outer loading (OL), composite reliability shown by Cronbach's Alpha and composite reliability, convergent reliability shown by average variance extracted (AVE) and discriminant validity shown by Fornell Larcker criterion and Heterotrait Monotrait (HTMT) ratio for each construct led to a decision to adopt the measurement model with only a slight modification to the resilience measurement model. An indicator (DT25) was deleted as the outer loading value was less than 0.400. According to Hair, Hult, Ringle and Sarstedt (2014), a value less than 0.400 should be removed from the measurement model. However, another indicator for resilience, D4 was retained because the value is between 0.40 and 0.60. Hair et al (2014) recommended that such indicator is considered for removal but if it does not affect the value of AVE and composite reliability, then the indicator should be retained.

Table 2 Measurement model assessment result

\begin{tabular}{|c|c|c|c|c|c|}
\hline Constructs & Indicator Reliability & Composite Reliability & $\begin{array}{c}\text { Convergent } \\
\text { Reliability } \\
\end{array}$ & Discriminant Validity & Decisions Taken \\
\hline Resilience & $\begin{array}{l}\text { All indicators have } \\
\text { acceptable outer } \\
\text { loadings }(>0.600) \\
\text { except for DT4 }(\mathrm{OL}= \\
0.593) \text { and DT25 (OL } \\
=0.373)\end{array}$ & $\begin{array}{l}\text { Cronbach's Alpha is } \\
0.969 \text { and Composite } \\
\text { reliability is } 0.972 \text {, } \\
\text { indicating acceptable } \\
\text { composite reliability }\end{array}$ & $\begin{array}{l}\text { AVE is } 0.583 \\
\text { indicating acceptable } \\
\text { convergent reliability }\end{array}$ & $\begin{array}{l}\text { Fornell Larcker } \\
\text { Criterion and HTMT } \\
\text { ratio indicated good } \\
\text { discriminant validity }\end{array}$ & $\begin{array}{l}\text { Indicator DT25 was } \\
\text { deleted but indicator } \\
\text { DT4 was retained. The } \\
\text { decision led to an } \\
\text { increase in AVE to } \\
0.602\end{array}$ \\
\hline Students' Involvement & $\begin{array}{l}\text { All indicators have } \\
\text { outer loading more } \\
\text { than } 0.708, \text { thus } \\
\text { showing high indicator } \\
\text { reliability }\end{array}$ & $\begin{array}{l}\text { Cronbach's Alpha is } \\
0.921 \text { and Composite } \\
\text { reliability is } 0.944, \\
\text { indicating acceptable } \\
\text { composite reliability }\end{array}$ & $\begin{array}{l}\text { AVE is } 0.809 \\
\text { indicating acceptable } \\
\text { convergent reliability }\end{array}$ & $\begin{array}{l}\text { Fornell Larcker } \\
\text { Criterion and HTMT } \\
\text { ratio indicated good } \\
\text { discriminant validity }\end{array}$ & $\begin{array}{l}\text { All indicators were } \\
\text { retained, measurement } \\
\text { model showed } \\
\text { statistically } \\
\text { acceptability }\end{array}$ \\
\hline $\begin{array}{c}\text { Classroom } \\
\text { Management }\end{array}$ & $\begin{array}{l}\text { All indicators have } \\
\text { outer loading more } \\
\text { than } 0.708, \text { thus } \\
\text { showing high indicator } \\
\text { reliability }\end{array}$ & $\begin{array}{l}\text { Cronbach's Alpha is } \\
0.891 \text { and Composite } \\
\text { reliability is } 0.925 \text {, } \\
\text { indicating acceptable } \\
\text { composite reliability }\end{array}$ & $\begin{array}{l}\text { AVE is } 0.754 \\
\text { indicating acceptable } \\
\text { convergent reliability }\end{array}$ & $\begin{array}{l}\text { Fornell Larcker } \\
\text { Criterion and HTMT } \\
\text { ratio indicated good } \\
\text { discriminant validity }\end{array}$ & $\begin{array}{l}\text { All indicators were } \\
\text { retained, measurement } \\
\text { model showed } \\
\text { statistically } \\
\text { acceptability }\end{array}$ \\
\hline Instructional Strategies & $\begin{array}{l}\text { All indicators have } \\
\text { outer loading more } \\
\text { than } 0.708, \text { thus } \\
\text { showing high indicator } \\
\text { reliability }\end{array}$ & $\begin{array}{l}\text { Cronbach's Alpha is } \\
0.915 \text { and Composite } \\
\text { reliability is } 0.940 \text {, } \\
\text { indicating acceptable } \\
\text { composite reliability }\end{array}$ & $\begin{array}{l}\text { AVE is } 0.798 \\
\text { indicating acceptable } \\
\text { convergent reliability }\end{array}$ & $\begin{array}{l}\text { Fornell Larcker } \\
\text { Criterion and HTMT } \\
\text { ratio indicated good } \\
\text { discriminant validity }\end{array}$ & $\begin{array}{l}\text { All indicators were } \\
\text { retained, measurement } \\
\text { model showed } \\
\text { statistically } \\
\text { acceptability }\end{array}$ \\
\hline $\begin{array}{c}\text { Perceived Practicum } \\
\text { Stress }\end{array}$ & $\begin{array}{l}\text { All indicators have } \\
\text { outer loading more } \\
\text { than } 0.60 \text {, thus } \\
\text { showing acceptable } \\
\text { indicator reliability }\end{array}$ & $\begin{array}{l}\text { Cronbach's Alpha is } \\
0.898 \text { and Composite } \\
\text { reliability is } 0.916, \\
\text { indicating acceptable } \\
\text { composite reliability }\end{array}$ & $\begin{array}{l}\text { AVE is } 0.523 \\
\text { indicating acceptable } \\
\text { convergent reliability }\end{array}$ & $\begin{array}{l}\text { Fornell Larcker } \\
\text { Criterion and HTMT } \\
\text { ratio indicated good } \\
\text { discriminant validity }\end{array}$ & $\begin{array}{l}\text { All indicators were } \\
\text { retained, measurement } \\
\text { model showed } \\
\text { statistically } \\
\text { acceptability }\end{array}$ \\
\hline
\end{tabular}




\section{Structural Model Assessment}

The structural model assessment result is shown in Table 3. The path coefficient, $\mathrm{T}$ statistics and $\mathrm{p}$ values of the relationships between constructs are indicated. The result showed that classroom management is a significant mediator between resilience and perceived practicum stress due to the significant relationship between resilience and classroom management $(t=10.142, p=0.000)$, and between classroom management and stress $(t=4.835, p=0.000)$. The relationship between resilience and stress is also significant $(t=7.229, p=$ 0.000). Instructional strategies and student involvement however, are not significant mediators because of the relationships between instructional strategies and stress $(p=1.294, t=0.204)$ and between student involvement and stress $(t=0.214, p=0.833)$ were not significant although the relationships between resilience and instructional strategies $(t=8.483, p=0.000)$ and between resilience and student involvement $(t=8.966, p=0.000)$ were significant. Figure 1 presents the bootstrapping output to show which relationships are significant and not.

Table 3 Bootstrapping result indicating the significance of the path coefficient between constructs

\begin{tabular}{lccc}
\hline \multicolumn{1}{c}{ Relationship of Constructs } & Path Coefficient & T statistics & P values \\
\hline Resilience $\rightarrow$ Classroom Management & 0,470 & 10.142 & 0.000 \\
Classroom Management $\rightarrow$ Stress & -0.432 & 4.835 & 0.000 \\
Resilience $\rightarrow$ Instructional Strategies & 0.431 & 8.483 & 0.000 \\
Instructional Strategies $\rightarrow$ Stress & -0.092 & 1.294 & 0.204 \\
Resilience $\rightarrow$ Students Involvement & 0437 & 8.966 & 0.000 \\
Students Involvement $\rightarrow$ Stress & -0.019 & 0.214 & 0.833 \\
Resilience $\rightarrow$ Stress & -0366 & 7.229 & 0.000 \\
\hline
\end{tabular}

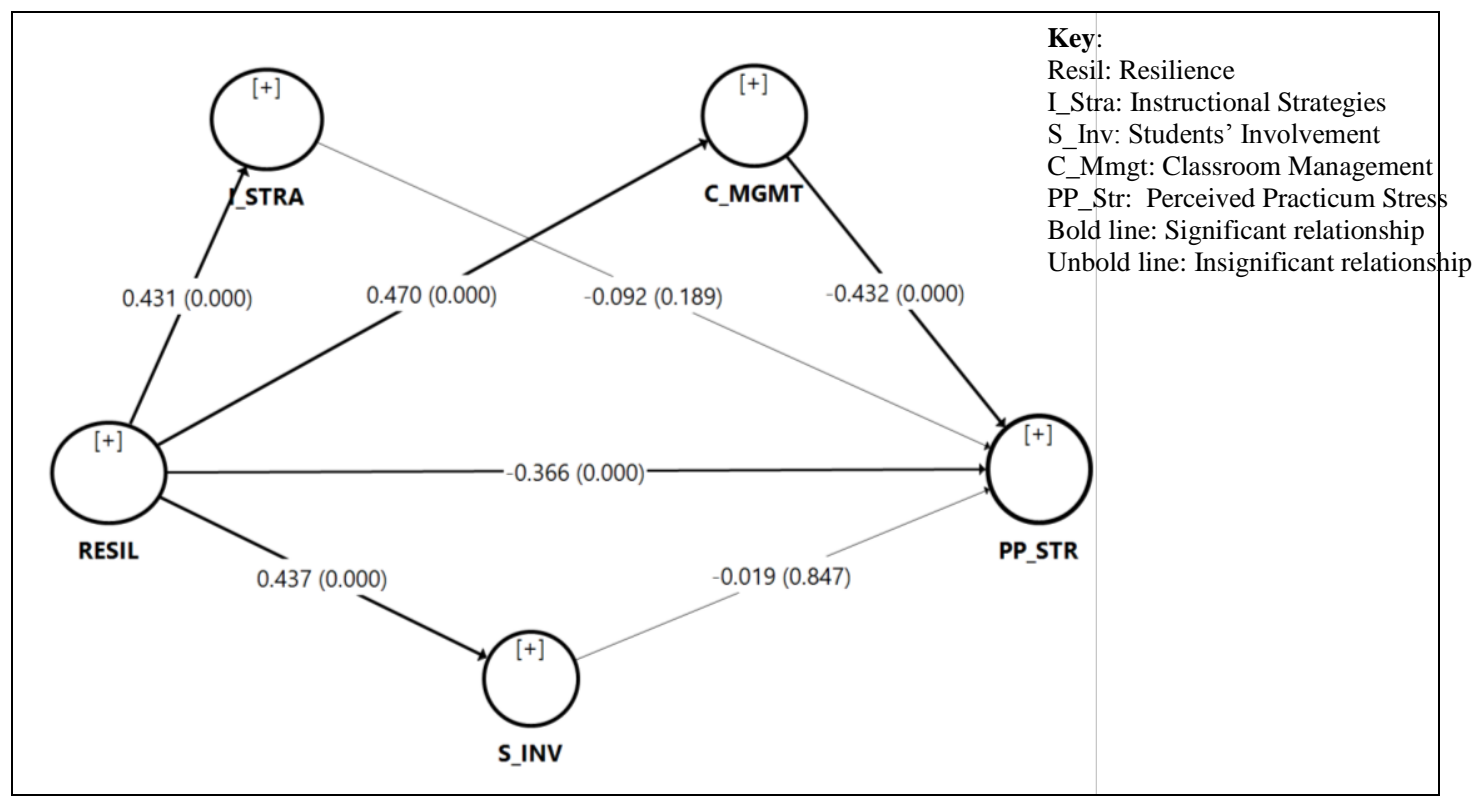

Figure 1 Bootstrapping output from SmartPLS3.0

Table 4 shows the effect of exogenous constructs on the endogenous constructs. It showed that resilience explained $22.0 \%$ of the variance in classroom learning, $18.5 \%$ of the variance in instructional strategies, and $19.1 \%$ of the variance in student invol vement. The inter-relationships of the exogenous constructs explained $59.7 \%$ of the variance in percei ved practicum stress. The $\mathrm{R}$ square value is prominently shown in Figure 2. This implies that classroom learning has a greater effect size, followed by student involvement and the least for instructional strategies.

Table 4 The R square values of the endogenous constructs

\begin{tabular}{lccc}
\hline \multicolumn{1}{c}{ Endogenous Constructs } & $\mathbf{R}^{\mathbf{2}}$ & T statistics & P values \\
\hline Classroom Management & 0.220 & 5.130 & 0.000 \\
Instructional Strategies & 0.185 & 4.244 & 0.000 \\
Student Involvement & 0.191 & 4.267 & 0.000 \\
Stress & 0.597 & 17.938 & 0.000 \\
\hline
\end{tabular}




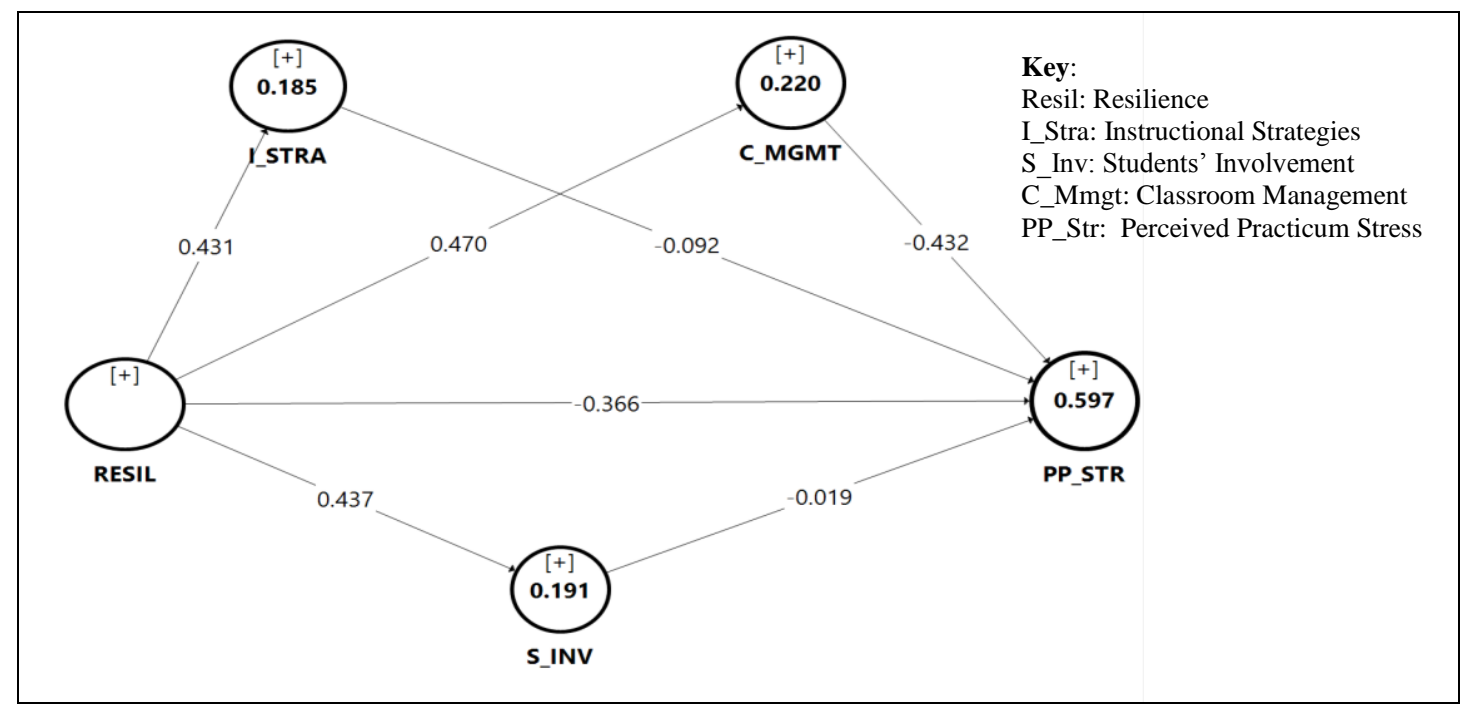

Figure 2 PLS algorithm output from SmartPLS3.0

The result showed that resilience contributes significantly to perceived practicum stress. The negative value of the path coefficient indicates that a high resilience will lead to reduced perceived practicum stress (Soave, 2014). Additionally, resilience also contributes significantly and positively to enhance efficacy in classroom management, students' involvement and instructional strategies. Hence, resilience provides the trainee teacher with greater conviction and belief that they will do a better job at managing the classroom. The confidence to manage classroom is also significantly related to lower the level of perceived prac ticum stress. In this study, classroom management is statistically proven as a significant mediator on the relationship between resilience and perceived practicum stress. However, students' involvement and instructional strategies do not exhibit significant mediating role as these two constructs are not significantly related to perceived stress. This is indicative that the main predictor of perceived practicum stress is classroom management and less of students' involvement and instructional strategies. Evertson and Weinstein (2006) explained that classroom management is critical to ensure the multiple learning goals of students are met. Trainee teachers need to develop competence in arranging the physical environment, establishing rules and procedures, maintaining students' attention to lessons and engagement in activities (Brophy, 2006). The responsibilities in classroom management itself is already quite daunting and in fact, slightly overlapping the tasks in students' involvement and instructional strategies. In other wo rds, being efficacious in classroom management means being able to handle students' involvement and instructional strategies too. Thus, it is evident that trainee teachers with greater efficacy in classroom management will have greater resilience that can reduce perc eived practicum stress significantly and this becomes the central dimension of self-efficacy that significantly help to cope with stress.

\subsection{CONCLUSION}

The results showed that trainee teachers have moderate level of resilience and self-efficacy as well as perceived practicum stress. The relationships between resilience with each dimension of self-efficacy were significant. The relationships between instructional strategies and student involvement with perceived practicum stress were insignificant except classroom management. This study concludes that classroom management is a significant mediator of the relationship between resilience and perceived practicum stress. Hence, this implies the need to improve trainee teachers' competence in classroom management in order to increase their resilience against practicum stress.

\section{References}

Abebe, S., \& Haile Mariam, A. (2011). Teacher Stressors and Potential Remedies from Pre-service Teachers and Cooperating Teachers' Perspectives. Eastern Education Journal, 40(1), 64-75.

Baloglu, N. (2008). The Relationship Between Prospective Teachers' Strategies for Coping with Stress and Their Perceptions of Student Control. Social Behavior and Personality, 36(7), 903-910.

Bandura, A. (1986). Fearful Expectations and Avoidant Actions as Coeffects of Perceived Self-Inefficacy. American Psychologist, $41(12), 1389-1391$.

Bandura, A. (1999). A Social Cognitive Theory of Personality. In L. Pervin \& O. John (Ed.), Handbook of Personality (2nd ed., pp. 154-196). New York: Guilford Publications. (Reprinted in D. Cervone \& Y. Shoda (Eds.), The Coherence of Personality. New York: Guilford Press.)

Bandura, A. (2001). Social Cognitive Theory: An Agentic Perspective. Annual Review Psychology, 52, 1-26.

Bandura, A. (2005). Evolution of Social Cognitive Theory. In K. G. Smith \& M. A. Hitt (Eds.), Great Minds in Management. Oxford: Oxford University Press.

Beltman, S., Mansfield, C., \& Price, A. (2011). Thriving Not Just Surviving: A Review of Research on Teacher Resilience. Educational Research Review, 6(3), 185207.

Bonanno, G. (2012). Uses and Abuses of Resilience Construct: Loss, Trauma, and Health Related Adversities. Social Science and Medicine, 74(5), 753-756.

Brophy, J. (2006). History of Research on Classroom Management. In C. M. Evertson \& C. S. Weinstein (Eds.), Handbook of Classroom Management: Research, Practice, and Contemporary Issues (pp. 17-43). Mahwah, NJ: Lawrence Erlbaum Associates.

Caires, S., Almeida, L. S., \& Martins, C. (2010). The Socioemotional Experiences of Student Teachers during Practicum: A Case of Reality Shock? The Journal of Educational Research, 103(1), 17-27. 
Canpolat, A. M. (2012). The Mediating Role of Self-Efficacy in the Relationship between Class Climates and Goal Orientations in Physical Education. World Applied Sciences Journal, 16(1), 76-85.

Castro, A., Kelly, J., \& Shih, M. (2010). Resilience Strategies for Teachers in High-Needs Areas. Teaching and Teacher Education, 26(3), 622-629.

Cohen, J. (1998). Statistical Power Analysis for the Behavioral Sciences (2nd edition). Hillsdale, NJ: Lawrence Erlbaum Associates.

Cohen, S., Kamarck, T., \& Mermelstein, R. (1983). A Global Measure of Perceived Stress. Journal of Health and Social Behavior, 24(4), 385-396.

Conner, D. R. (1993). Managing at the Speed of Change: How Resilient Managers Succeed and Prosper Where Others Fail. New York, NY: Villard Books.

Deniz, N., Noyan, A., \& Ertosun, O. G. (2015). Linking Person-Job Fit to Job Stress: The Mediating Effect of Perceived Person-Organization Fit. Procedia - Social and Behavioral Sciences, 207, 369-376.

Evertson, C. M., \& Weinstein, C. S. (2006). Classroom Management as a Field of Inquir, in Evertson, C. M., \& Weinstein, C. S. (Ed). Handbook of Classroom Management: Research, Practice, and Contemporary Issues. Mahwah Lawrence Erlbaum, 3-15.

Farooqui, S., \& Nagendra, A. (2014). The Impact of Person Organization Fit on Job Satisfaction and Performance of the Employees. Procedia Economics and Finance, 11, 122-129.

Farrell, T. (2008). Here's the Book, Go Teach the Class, ELT Practicum Support. RELC Journal, 39(2), 226-241.

Fives, H. (2003). Exploring the Relationships of Teachers' Efficacy, Knowledge, and Pedagogical Beliefs: A Multimethod Study (PhD unpublished). University of Maryland, College Park, Maryland, United States.

Flach, F. (1988). Resilience: Discovering a New Strength at Times of Stress. New York, NY: Fawcett Columbine.

French, J.R.P., \& Caplan, R.D. (1972). Occupational Stress and Individual Strain, in A.J. Marrow (Ed.). The Failure of Success, New York: Amacom, pp. 30-66.

Garmezy, N., \& Masten, A. S. (1986). Stress, Competence, and Resilience: Common Frontiers for Therapist and Psychopathologist. Behavior Therapy, 17(5), 500521.

Goh, P. S., \& Matthews, B. (2011). Listening to the Concerns of Student Teachers in Malaysia during Teaching Practice. Australian Journal of Teacher Education, $36(2), 12-23$

Hair, J. F., Sarstedt, M., Ringle, C. M., \& Mena, J. A. (2012). An Assessment of the use of Partial Least Squares Structural Equation Modeling in Marketing Research. Journal of the Academy of Marketing Science, 40(3), 414-433.

Hair, J. F., Sarstedt, M., Pieper, T. M., \& Ringle, C. M. (2012). The Use of Partial Least Squares Structural Equation Modeling in Strategic Management Research: A Review of Past Practices and Recommendations for Future Applications. Long Range Planning, 45(5-6), 320-340.

Hair, J. F., Hult, G. T. M., Ringle, C., \& Sarstedt, M. (2014). A Primer on Partial Least Squares Structural Equation Modeling (PLS-SEM). London: SAGE Publications, Incorporated.

Hamaidi, D., Al-Shara, I., Arouri, Y., \& Awwad, F. A. (2014). Student-teachers' Perspectives of Practicum Practices and Challenges. European Scientific Journal, 10(13), 191-214.

Henseler, J., Ringle, C.M., \& Sinkovics, R.R. (2009). The Use of Partial Least Squares Path Modeling in International Marketing, in Sinkovics, R. R. \& Ghauri, P. N. (eds.), Advances in International Marketing (AIM), 20, Bingley, 277-320.

Hökerberg, Y. H. M., Reichenheim, M. E., Faerstein, E., Passos, S. R. L., Fritzell, J., Toivanen, S., \& Westerlund, H. (2014). Cross-cultural Validity of the DemandControl Questionnaire: Swedish and Brazilian workers. Revista de Saúde Pública, 48(3), 486-496.

Hong, J. Y. (2012). Why Do Some Beginning Teachers Leave the School, and Others Stay? Understanding Teacher Resilience through Psychological Lenses. Teachers and Teaching: Theory and Practice, 18(4), 417-440.

Karasek, R. A., \& Theorell, T. (1990). Healthy work: Stress, Productivity and the Reconstruction of Working Life. New York: Basic Books.

Kyriacou, C., \& Stephens, P. (1999). Student Teachers' Concerns during the Teaching Practice. Evaluation and Research in Education, 13(1), 18-31.

Lane, J.D., Seskevich, J.E., \& Pieper, C.F. (2007). Brief Meditation Training Can Improve Perceived Stress and Negative Mood. Alternative Therapies in Health \& Medicine, 13(1), 38-44

Lazarus, R.S. (1991). Psychological Stress in the Workplace. Journal of Social Behavior and Personality, 6, 1-13.

Lazarus, R. S., \& Folkman, S. (1984). Stress, Appraisal, and Coping. New York: Springer.

Ledesma, J. (2012). Narratives of Longevity from the Perspective of Seventh-day Adventist School Administrators in North America: A Multiple Case Study (PhD Dissertation). Andrews University.

Lee, L., Petter, S., Fayard, D., \& Robinson, S. (2011). On the Use of Partial Least Squares Path Modeling in Accounting Research. International Journal of Accounting Information Systems, 12(4), 305-328.

Leon, K. A., Hyre, A.D., Ompad, D., DeSalvo, K. B., \& Muntner, P. (2007). Perceived Stress among a Workforce 6 Months Following Hurricane Katrina. Social Psychiatry and Psychiatric Epidemiology, December, 42(12), 1005-1011.

Maddux, J.E. (2011). Self-efficacy: The Power of Believing You Can. In Snyder, C. R., \& Lopez, S.J. (eds). Handbook of Positive Psychology. Oxford University Press: New York.

Malinauskas, R., Malinauskiene, V., \& Dumciene, A. (2010). Burnout and Perceived Stress among University Coaches in Lithuania. Journal of Occupational Health, 52(5), 302-307.

McGrath, J. (1984). Groups: Interaction and Performance. Englewood Cliffs, NJ: Prentice-Hall.

Mohamadi, F. S., \& Asadzadeh, H. (2012). Testing the Mediating Role of Teachers' Self-Efficacy Beliefs in the Relationship between Sources of Efficacy Information and Students Achievement. Asia Pacific Education Review, 13(3), 427-433.

Mutlu, G. (2015). Challenges in Practicum: Two Sides of the Coin. International Journal of Learning and Teaching, 7(1), 38-48.

NIOSH, 2002. Stress Definition. Retrieved from www.cdc.gov/niosh/stresswk.htm

Nishikawa, Y. (2006). Thriving in the Face of Adversity: Perceptions of Elementary-School Principals. La Verne, CA: University of La Verne.

O'Leary, V. E. (1998). Strength in the Face of Adversity: Individual and Social Thriving. Journal of Social Issues, 54(2), 425-446.

Peng, D. X., \& Lai, F. (2012). Using Partial Least Squares in Operations Management Research: A Practical Guideline and Summary of Past Research. Journal of Operations Management, 30(6), 467-480.

Perry, B. (2002). How children become resilient. Scholastic Parent \& Child, 10(2), 33-35.

Pinto, J. K., Dawood, S., \& Pinto, M. B. (2014). Project Management and Burnout: Implications of the Demand-Control-Support Model on Project-Based Work. International Journal of Project Management, 32(4), 378-589.

Qureshi, R. (2015). They are Able Who Think They Are Able: Relationship between Self-Efficacy and In-Service Teacher Education. International Journal on New Trends in Education and Their Implications, April, 6(2), 93-103.

Ralph, E. (2007). The Practicum in Professional Education: Pre-service Students' Experiences. Transformative Dialogues: Teaching \& Learning Journal, 1(2), 1-17.

Rieg, S.A., Paquette, K.R., \& Chen, Y. (2007). Coping with Stress: An Investigation of Novice Teachers' Stressors in the Elementary Classroom. Education, 128(2), 211-217.

Ringle, C. M., Sarstedt, M., \& Straub, D.W. (2012). A Critical Look at the Use of PLS-SEM in MIS Quarterly. MIS Quarterly, 36(1), iii-xiv.

Saakvitne, K. W., Tennen, H., \& Affleck, G. (1998). Exploring Thriving in the Context of Clinical Trauma Theory: Constructivist Self-Development Theory. Journal of Social Issues, 54(2), 279-299.

Saricam, H. (2015). Mediating Role of Self-Efficacy on the Relationship between Subjective Vitality and School Burnout in Turkish Adolescents. The International Journal of Educational Researchers, 6(1), 1-12.

Sarstedt, M., Ringle, C. M., Smith, D., Reams, R., \& Hair, J. F. (2014). Partial Least Squares Structural Equation Modeling (PLS-SEM): A Useful Tool for Family Business Researchers. Journal of Family Business Strategy, 5(1), 105-115.

Soave, A. E. (2014). Examining the Relationship of Variables Associated with Pre-Service Teachers' Coping during Their Practicum Experience. University of Western Ontarion - Electronic Thesis and Dissertation Repository Paper 1958.

Sosa, T., \& Gomez, K. (2012). Connecting Teacher Efficacy Beliefs in Promoting Resilience to Support of Latino Students. Urban Education, 47(5), 876-909. 
Sosik, J. J., Kahai, S. S., \& Piovoso, M. J. (2009). Silver Bullet or Voodoo Statistics? A Primer for Using the Partial Least Squares Data Analytic Technique in Group and Organization Research. Group Organization Management, 34(1), 5-36.

Tschannen-Moran, M., \& Woolfolk Hoy, A. (2001). Teacher Efficacy: Capturing and Elusive Construct. Teaching and Teacher Education, 17(2001), 783-805.

Tuli, F. \& File, G. (2009). Practicum Experience in Teacher Education. Ethiopian Journal of Education and Science, 5(1), $107-116$.

Wagnild, G. M., \& Young, H. M. (1990). Resilience among Older Women. Image: Journal of Nursing Scholarship, 22(4), 252-255.

Wagnild, G. M., \& Young, H. M. (1993). Development and Psychometric Evaluation of the Resilience Scale. Journal of Nursing Measurement, 1(2), 165-178.

Waldman, S.V., Diez, J.C., Arazi, H.C., Linetzky, B., Guinjoan, S., \& Grancelli, H. (2009). Burnout, Perceived Stress, and Depression among Cardiology Residents in Argentina. Academic Psychiatry, 33(4), 296-301.

Wong, K. K. K. (2013). An Assessment of the use of Partial Least Squares Structural Equation Modelling (PLS-SEM) Techniques using SmartPLS. Marketing Bulletin, 24(1), 1-32.

Wood, R., \& Bandura, A. (1989). Social Cognitive Theory of Organizational Management. Academy of Management Review, 14(3), 361-384. 